\title{
LA VIDA DESPUÉS DE LA VIDA NOTAS EN TORNO AL ATLAS DE LA POESÍA ARGENTINA
}

Sobre Eugenia Straccali y Bruno Crisorio (Coord.). Atlas de la poesía argentina. La Plata: Editorial de la Universidad de La Plata, 2017, 369 pp. Ilustraciones: Federico Luis Ruvituso.

Germán Osvaldo Prósperi

Universidad Nacional de La Plata

Proponer un atlas de la poesía conlleva ciertos riesgos. En principio, abandonar (aunque no excluir) una visión lineal de la historia de la poesía: correr el velo protector de Cronos, quedar a la intemperie, bajo el cielo nocturno. Pero también restituir el poema a un lugar esencial, no por más originario o fundamental, sino por más precario y decididamente disruptivo. El proyecto de un Atlas poético supone, además, una reconfiguración de la poesía en relación al tiempo, al espacio, al sujeto; en suma, un replanteamiento del vínculo, complejo pero ineludible desde Aristóteles, entre poesía e historia.

Basta leer el prólogo del Atlas de la poesía argentina para percatarse que una figura, entre varias mencionadas allí, ha funcionado como fuente directa de inspiración, tanto desde un punto de vista conceptual cuanto metodológico: Aby Warburg. Podríamos decir que el lugar y la función que posee el concepto en la filosofía hegeliana le corresponde a la imagen en la concepción warburguiana. De tal manera que, si para Hegel la historia del Espíritu no es sino una ciencia de la experiencia de la conciencia, la historia (del arte o de la poesía) 
para Warburg no es sino una ciencia de la experiencia de la imaginación.

¿Qué vida - se preguntaba el historiador del arte alemán define a las imágenes, pero también a los textos, cuando no son actualizados por nadie? ¿Qué sucede con las imágenes cuando nadie las mira, y con los textos cuando nadie los lee? ¿Cómo entender, en suma, estas vidas que parecen sobrevolar o, si pudiera decirse, sub-volar la historia convencional, la historia cronológica que rige el devenir de los acontecimientos relatados en los manuales de historia? El Atlas Mnemosyne y la célebre Biblioteca constituyen las respectivas respuestas a estos interrogantes. El Atlas se configura como un espacio de imágenes, como una serie de constelaciones posibles entre las imágenes. La Biblioteca, por su parte, como un espacio de enunciados, como una serie de constelaciones (familias, dirá Foucault en L'archéologie du savoir) posibles entre los enunciados. Ambas series poseen una vida específica que no se confunde con su existencia efectiva actual, es decir con su actualización por parte de un sujeto. El libro cerrado, abandonado en algún anaquel de una biblioteca, posee una vida propia, irreductible a la actualización de la lectura, una vida extremadamente frágil y precaria. Lo mismo sucede con las imágenes cuando no son vistas por nadie. Warburg reservó el término Nachleben, supervivencia o vida póstuma, para designar esta condición de las imágenes, pero que podemos extender sin duda a todos los fenómenos culturales que existen bajo el modo de la potencia. En este sentido, tanto el Atlas Mnemosyne como la Biblioteca son verdaderos dispositivos o máquinas de actualización y potencialización de las imágenes y los enunciados, materiales plásticos capaces de absorber los objetos impensados por la historia del arte, metamorfoseándose constantemente, sin fijarse nunca en un resultado definitivo, en una síntesis o un saber absoluto. Se 
trata de una Memoria cósmica u ontológica, no subjetiva ni humana. A diferencia de la Memoria hegeliana, de la Erinnerung como recuerdo interiorizador del sentido, a diferencia pues del saber absoluto como memoria universal, la memoria warburguiana alberga las fallas y las intermitencias del sentido, los vacíos y las fracturas que interrumpen la trama histórica.

¿Sorprenderá que esa interrupción sea precisamente la ocasión propicia, el kairos, para la emergencia, no ya presente, no ya fenomenológica, de la imagen? La imagen dialéctica de Walter Benjamin marca la cesura del pensamiento (es decir de lo Real tout court, según Hegel), el punto en el que irrumpe lo que Antonin Artaud llamaba el impoder del pensamiento. No se trata entonces de una negación, sino de una neutralización de la Idea; la dialéctica no es negada, sino detenida (Dialektik im Stillstand). El término neutro, del cual Maurice Blanchot nos ha dejado reflexiones esclarecedoras, resulta en este punto decisivo: ne...uter, ni/ni. Esta fórmula, ni...ni, designa el espacio o, más bien, el movimiento de apertura, el espaciamiento que se instaura entre los dos términos de la dialéctica para que surja allí la imagen. En este sentido, el Atlas no es sino el espacio específico de la imaginación. El poema es un umbral que nos permite acceder a este espacio intermedio entre lo corpóreo y lo incorpóreo, entre la naturaleza y el espíritu. Frente al mundus historicus, cuyo desarrollo racional describe la dialéctica hegeliana, el poema nos introduce en otro mundo, acaso el mismo pero dislocado, que podríamos denominar, retomando una expresión de Henry Corbin, mundus imaginalis. Este mundo específico de la imaginación posee su propia topografía y su propia temporalidad. No es el tiempo lineal de la cronología sino un tiempo alternante, discontinuo, habitado a su vez por ritmos y tiempos diferentes. El Atlas de la poesía argentina, en este sentido, nos introduce 
en una geo-grafía o, podríamos decir con más propiedad, en una urano-grafía o astro-grafía propiamente poéticas. No se trata, sin embargo, de un tiempo y de un espacio simplemente externo al de la historia, sino intra-histórico. Como si el desarrollo histórico de la Idea se viese atravesado por una falla o una fractura. El poema nos adentra en ese hiato en el que sobreviven las imágenes y los fantasmas. Leemos en el prólogo al Atlas de la poesía argentina: "La poesía abre ese espacio, esa grieta en la que irrumpen sentidos ocultos que como estrellas están en el universo antes que el hombre" (p. 11). Relación esencial, entonces, entre el poema y la grieta (el schisma) del sentido. Se comprenderá por qué Warburg ha podido sostener que "toda la humanidad es eternamente esquizofrénica" (citado en Gombrich 1970, p. 223).

Todo poema establece una estructura provisoria, un sistema de relaciones entre elementos heterogéneos, en suma, una constelación en el cielo nocturno del lenguaje. Immanuel Kant se preguntó alguna vez qué significaba, para el filósofo, orientarse en el pensamiento; la misma pregunta podría realizarse en lo que concierne a la poesía: ¿qué significa, para el poeta, orientarse en el lenguaje? El espacio del lenguaje es como un cielo oscuro. En la superficie opaca de la noche, el poeta hace resplandecer ciertos enunciados y teje una red de relaciones entre ellos. Dicho de otro modo: constela. Los atlas estelares siempre funcionaron como instrumentos de orientación, sobre todo para los navegantes. Se trata de figuraciones imaginarias que instauran una posible cartografía en la noche del sentido. Cada uno de los poemas reunidos en esta antología funciona como una ventana a este mundus imaginalis. No sorprende, entonces, que el Atlas en cuanto tal se constituya en un verdadero dispositivo de visión. ¿Qué permite ver, en definitiva, este Atlas poético? Arriesgamos: permite ver la vida más allá o más acá de la vida, la vida 
fantasmal de las imágenes y de los textos, lo que de irremediablemente póstumo hay en las vidas que proliferan en el mundus imaginalis. Algo se vuelve visible y decible en cada poema. Cada uno de ellos es una ocasión de actualización de estas vidas potenciales que sobreviven en la imaginación.

Vuelvo a la pregunta de Warburg: ¿qué vida define a las imágenes y a los textos cuando no son actualizados por nadie? El Atlas de la poesía argentina, en la medida en que combina ambos registros, el textual y el visual, la maravillosa escritura de los poetas y las imágenes, también maravillosas, de Federico Ruvituso, pero también las imágenes contenidas en los poemas y la poesía contenida en los dibujos, constituye la mejor respuesta a este interrogante. De algún modo custodia, con profundo respeto y sensibilidad, la precariedad y belleza de estos poemas e imágenes, la vida inconclusa de los espectros que yacen en el corazón del tiempo. Leer este texto, entonces, supone actualizar una vida póstuma, una Nachleben, pero al mismo tiempo requiere mantener esa vida en su fragilidad esencial, en su condición provisoria y evanescente. Se sabe que siempre sobrevive un resto en todo proceso de actualización, una suerte de residuo en todo acto de lectura. El proyecto de este Atlas, entonces, se revela enseguida enorme y fascinante. Como si ese resto, en su condición prácticamente extraontológica, se hubiese convertido, de repente, en el hilo conductor del libro mismo. Leemos allí, experimentamos, las sombras que acosan toda lectura, los fantasmas que acechan en los recodos de todo proceso de actualización. Esta atención a la vida de la potencia es uno de los puntos más destacables $-\mathrm{y}$ no el único - de este libro imprescindible. Se propone allí, en definitiva, una experiencia (de lectura, es decir de visión) en la que descubrimos una vida que, más allá o más acá de la vida actual a la que estamos habituados, se agita no obstante en el centro, siempre descentrado, de nosotros mismos. Leer este 
Atlas significa acceder a lo más precario de nuestras vidas, a lo que en ellas pareciera haberse sustraído a su condición actual y utilitaria; acceder, en suma, a nuestro estatuto irremediablemente fantasmático. Acaso la verdadera vida, a pesar de Arthur Rimbaud, no esté después de todo ausente. Quizás la poesía, como el arte, pero también - me atrevo a decir - como la filosofía, nos permita acceder a esta ausencia o, más bien, al punto de indistinción entre la ausencia y la presencia que es, como sabemos, el lugar paradójico y siempre evasivo de las imágenes. En ese lugar, sin duda, los poemas recopilados en este libro fundamental adquieren su brillo estelar, incandescente, y su belleza más profunda.

\section{Referencias bibliográficas}

Straccali, E. y Crisorio, E. (coord.), (2017). Atlas de la poesía argentina. La Plata: Editorial de la Universidad de La Plata.

Gombrich, E. (1970). Aby Warburg. An Intellectual Biography. London: The Warburg Institute. 